The Social Sciences 14 (4): 212-216, 2019

ISSN: $1818-5800$

(C) Medwell Journals, 2019

\title{
Utilizing Drama as an Exploration of Knowledge and Learning
}

\author{
${ }^{1}$ Deri Sis Nanda, ${ }^{1}$ Susanto and ${ }^{2}$ Malik \\ ${ }^{1}$ Department of English Education, \\ ${ }^{2}$ Department of Public Administration, Universitas Bandar Lampung, Lampung, Indonesia
}

\begin{abstract}
We conducted a study on utilizing drama as an exploration of knowledge and learning for primary schools in teaching English as a Foreign language. The exploration aimed at understanding the student's interests, abilities and motivations. Then, we observed the teacher's perceptions in the classrooms during the implementation of the drama for the students. In the study, we find that students show their good engagement and comprehension abilities. However, the perceptions of the teachers varied on the several aspects of the student's preparation and performance. Further, their perceptions reflect the pedagogical context offering possibilities for cultural production in language learning. The research results underline how the drama can be used to construct the abilities for early language learners, especially, for social engagement and language comprehension.
\end{abstract}

Key words: Drama, learning, social engagement, language comprehension, possibilities, comprehension

\section{INTRODUCTION}

Each individual may have different interests, abilities and motivations (Chamorro-Premuzic et al., 2011). Understanding the knowledge and learning of these differences can be explored to generate and articulate ideas as in the context of Foreign language learning. For the exploration of student's differences in learning Foreign language an interaction framework may transform into creative dialogue such as that in utilizing drama for an explorative way. In the exploration, sharing ideas and opinions among students and teachers can introduce performance outcomes, skills and knowledge (Even, 2008; Richards and Rodgers, 2001).

In exploring and understanding student's interests, abilities and motivations, we conducted a study on utilizing drama as an exploration of knowledge and learning for primary schools in teaching English as a Foreign language in Indonesia. Then, we observed the teacher's perceptions in the classrooms during the implementation of the drama for the students. In the country, English is considered as a Foreign language and taught in every level of education from primary school to university level. Unfortunately, the Indonesian education system does not have the distinction between second and Foreign language studies. The system only has the distinction among national, ethnic and Foreign language studies.

As a Foreign language, English is only learnt during formal and non-formal education and it is not used on a daily basis in the country. Various pedagogical techniques and innovations have been applied in Foreign language learning classroom to drive the student's four language skills such as reading, listening, writing and speaking. However, in many cases, especially, in the province of Lampung, the student's language skills do not develop as expected in the designed curriculum. Since, then, it has been a debated problem for education system in Indonesia, especially with the focus on the student's differences in interests, abilities and motivations in learning Foreign language. As an alternative to respond the problem, we propose English drama pedagogy as a teaching tool to explore and understand the student's interests, abilities and motivations.

Featuring trends in English teaching for primary schools in Lampung-Indonesia: In the province of Lampung, Indonesia, primary schools are allowed to prepare their students for the growing influence of English as Foreign language competence. Models for English teaching in primary schools have been used but the effectiveness of the models is being debated comparing with their counterparts with two standing out in particular. The first is national language education (i.e., Indonesian language) which is a core subject strengthening the national identity. The second is ethnic language education (i.e., Lampung language) which has the emphasis on preserving the cultural based knowledge (Table 1). Therefore, models for language teaching (i.e.,

Corresponding Author: Deri Sis Nanda, Department of English Education, Universitas Bandar Lampung, Lampung, Indonesia 
Table 1: Philosophical outcomes in language education for primary schools Curriculum Outcomes

National language education Strengthening the national identity Ethnic language education Preserving the cultural based knowledge Foreign language education Preparing basic skills for globalized world with Foreign language competence

English, Indonesian and Lampung languages) are potential to compete each other. The competition affects the public policy for reducing the Foreign language education. Implementing drama pedagogy offers the compensation of the reduction by teaching English through extracurricular activities. Besides, the resources in national and ethnic languages can be used for drama activities, e.g., ethnic stories

Drama pedagogy: Drama pedagogy can be defined as a collection of drama based teaching and learning strategies to engage students with the content they are learning (Lee et al., 2015). Researchers have explored the advantages of the pedagogy for primary students as by Straksiene (2015) and elementary students as by Cremin et al. (2006), Demircioglu (2010) and DuPont (1992). It has also been explored for secondary learners (Keehn et al., 2008; Certo and Brinda, 2011; Rothwell, 2011) and adult learners (Nordin et al., 2012). In the exploration, it is highlighted that using drama pedagogy as teaching tool can improve the students in learning English. Not only does it help to learn language but it can improve their literacy skill such as understanding and learning the lives, culture and wisdom. Further, Bolton (1984), confirms that using drama as education is effective to help students to understand live experiences that they do not have.

Drama pedagogy as teaching tool is an integrated form which is useful for language learning. However, for language teachers, involving students in drama activities is a challenging task. When drama pedagogy activities, e.g., role-play are conducted in classroom, the students are invited to engage in the content discussion, share their thoughts and opinions about characters and motivations. Besides, they are encouraged to rethink and explore their perceptions about a situation. It can draw their attention and drive discussion among them. Then, they are eager to play. As the result, the activities can speed up the learning process and enrich the classroom environment (Robinson and Aronica, 2015).

Considering its advantages, we utilized English drama pedagogy as a teaching tool in language learning classrooms for primary schools in Lampung, Indonesia. Then, we try to explore the teacher's perceptions of using the pedagogy.



Fig. 1: A design for acquiring the teacher's perception on the implementation of English drama pedagogy

\section{MATERIALS AND METHODS}

The research was designed in qualitative method. It focused on the description of implementing drama pedagogy in English learning classrooms of 10 primary schools in Lampung, Indonesia. The drama was derived from ethnic stories in Indonesia which are converted into English. The research was also designed to study the perception of the teachers when they used English drama pedagogy for their students in the classrooms. Figure 1 shows the design used for acquiring the teacher's perception on the implementation of English drama pedagogy.

In the study, perceptions are defined as the sensory experiences which involve both the recognition of environmental actions as well as the response to those actions (Yates, 2007). The participants are 30 English teachers from the primary schools both public and private in Lampung. The schools are located in the town and rural areas. The teachers are experienced and certified for their teaching service. Data were collected from audio recorded interviews. The interviews were conducted in relaxed and open settings after they implemented drama activities. The responses gained from the interviews were transcribed and coded based on the themes.

\section{RESULTS AND DISCUSSION}

English drama activities: The drama played by the students was taken from the ethnic stories such as Malin Kundang, a folk tale from West Sumatra, Indonesia. The folk tale talks about the retribution on an ungrateful son. It is chosen because the story has local wisdom to learn in the classroom. It is observed that before the students performed the drama, the teachers designed and organized the drama activities in the classrooms with 


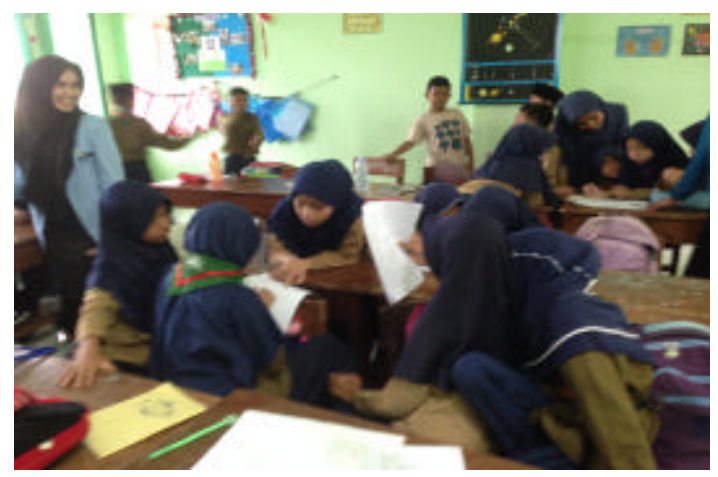

Fig. 2: The students are directed by the teacher in the preparation of English drama performance

some difficulties because they do not have the educational background in theater study. In practice, the content of the drama activities was designed based on the teacher's curricula unit (Fig. 2).

The teachers designed and organized each activity into several sections such as description, goals, rationale, guidelines, debrief and reflection. Then, the activities were combined with reading and writing assignments in the classroom. Some activities were with the involvement of the teacher in role play. The others involved the teacher as a facilitator. In role play and as a facilitator, it is found that the teachers welcomed the improvisation by the students and themselves. With the teacher involvement, the drama pedagogy activities were designed with the understanding that the teacher and the students had the shared experience using drama pedagogy in the classroom. It is as suggested by Bruner (1983), Golinkoff et al. (2006) and Zigler and Bishop-Josef (2006) that drama pedagogy activities bring the involvement of not only the student but also the teacher.

When the teacher gets involved in the drama activity, we observed that the teacher helps the students discover the ability to explore and understand the situations. It can be useful for the students to develop creativity and communicative competence. The student's creativity in the drama activities helped the students developed the language use spontaneously. The teacher involvement also helps to prepare the students to understand self-knowledge to face real-life situations, since, the teacher facilitates the activities with the use of academic content and social experiences. As stated in Baldwin and Fleming (2003), creative thinking and self-knowledge can be acquired through the use of drama in education. Moreover, we find that the activities bring the students engaged in learning situation. The engaged with the content they are learning (Fig. 3).

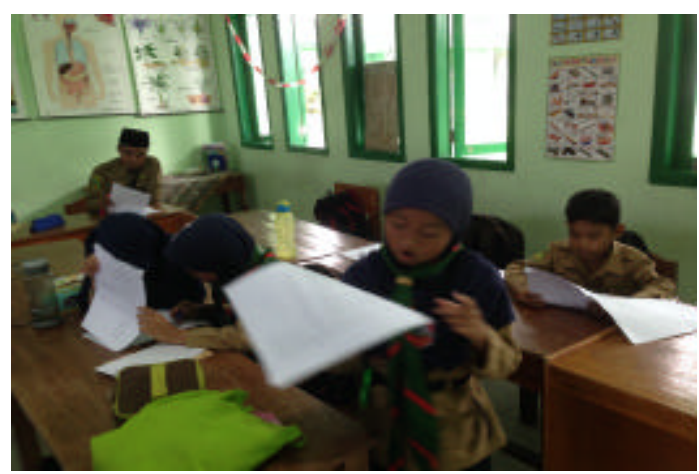

Fig. 3: The students are reciting the text with the supervision of the teacher

Teacher's perception: The teachers gave various responses after they were interviewed. Basically what their responses are positive regarding English drama pedagogy as an effective tool for either teaching or learning. Figure 4 shows the scoring values indicate the teacher's perception on the implementation of English drama pedagogy. In one response, they agreed that the pedagogy is a good alternative way to develop pronunciation skill in communicative competence in the target language English. But they opined it is hard for the students as young learners to pronounce the English words found in the drama that they never listen because they are Indonesian natives.

In another response, the teachers informed that they in the beginning did not know what to do with the drama pedagogy, especially, in English due to no experience in English drama activities. Then, the teachers need much time to learn by themselves and explain the activities to the students. And they continued to struggle with explaining and setting up each activity for students. Despite the struggles, teachers said that by doing drama pedagogy activities they see the student's progress in pronouncing English words as well as sentences.

The teachers also responded that they found the improvement in the student's understanding on the English text. It was shown when the drama activities began, the students understood the information. As an example, they knew how a main character in the drama feels, e.g., the mother of Malin Kundang and they could criticize why she behaves in a particular way when she is not recognized as the mother by her own son. It encouraged the students to learn the moral value in the cultural production depicted in the character.

Moreover, the teachers saw that the students got confident to speak in English and they attempted to make connection with the characters as such Malin Kundang his mother and his wife. They are eager to give some 


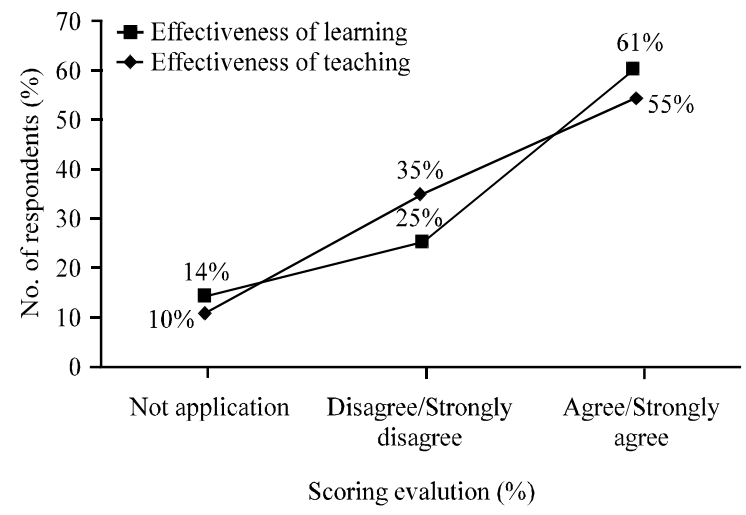

Fig. 4: The scoring evaluation of the teacher's perception on the implementation of English drama pedagogy

comments about the characters after the teachers gave the explanation. They pointed out that the students were completely engaged with those activities and the class became more dynamic through active cooperation of the classmates. For the teachers, the involvement of the students in the discussion on the characters shows their growing interest facilitated with their confidence to use and speak English.

Among those advantages, the teachers also responded about the difficulty for implementing English drama pedagogy as a teaching tool in language learning classrooms for primary schools in Indonesia. It is about the policy that English is not a core subject in the school. As the consequence, the subject gets less class meetings. For teachers, it is difficult to set the time to implement the pedagogy, especially, for the students involved in the activities.

\section{CONCLUSION}

Studying the implementation of English drama pedagogy as a teaching tool for primary schools, we explored the drama activities in the language classrooms and the teacher's perceptions. In our observation, the pedagogy contributed for building the student's abilities for social engagement and language comprehension. Those abilities were enhanced in drama activities with the involvement of the teacher in role play and as a facilitator. Although, some difficulties were found in designing and organizing the activities due to lack of theatre education but in practice they worked based on the curricula unit.

Meanwhile in the perceptions of the teachers, we could examine how various their responses which are basically positive, i.e., the pedagogy can be effective for teaching and learning. The pedagogy is regarded as a good alternative for teaching pronunciation. Although, the students face that English words are not easy to learn because of its difference from Indonesian, the teachers saw the student's progress in pronouncing English words as well as sentences. Besides, the teachers responded that they found the student's improvement in understanding English text, e.g., by explaining and criticizing the characters. For the teachers, these made the class more dynamic with the student's involvement in the discussion and their confidence to speak English. Unfortunately with the current policy treating English as not a core subject in the school, time constraints are the problems for implementing the pedagogy.

\section{LIMITATIONS}

This research is an exploratory study on the implementation of English drama pedagogy as a teaching tool for primary schools under the Indonesian context in Lampung Province and the teacher's perception of using the pedagogy in the classrooms. The number of schools involved may not fully represent the primary school population.

\section{ACKNOWLEDGEMENTS}

The research described in this study was supported by a research grant from the Ministry of Research, Technology and Higher Education of Indonesia (PTUPT Scheme, 2018). The researchers also thank the principals, teachers and students in the participating schools.

\section{REFERENCES}

Baldwin, P. and K. Fleming, 2003. Teaching Literacy through Drama: Creative Approaches. Routledge, London, England, UK., ISBN:9780415255783, Pages: 144.

Bolton, G.M., 1984. Drama as Education: An Argument for Placing Drama at the Centre of the Curriculum. 2nd Edn., Longman, Harlow, England, UK., ISBN:9780582361980, Pages: 202.

Bruner, J., 1983. Play, thought and language. Peabody J. Educ., 60: 60-69.

Certo, J. and W. Brinda, 2011. Bringing literature to life for urban adolescents: Artistic, dramatic instruction and live theater. J. Aesthetic Educ., 45: 22-37.

Chamorro-Premuzic, T., S.V. Stumm and A. Furnham, 2011. The Wiley-Blackwell Handbook of Individual Differences. Wiley Blackwell, West Sussex, South of England, ISBN:978-1 -444-33438-8, Pages: 848 . 
Cremin, T., K. Goouch, L. Blakemore, E. Goff and R. Macdonald, 2006. Connecting drama and writing: Seizing the moment to write. Res. Drama Educ. J. Appl. Theater Perform., 11: 273-291.

Demircioglu, S., 2010. Teaching English vocabulary to young learners via drama. Procedia Soc. Behav. Sci., 2: 439-443.

DuPont, S., 1992. The effectiveness of creative drama as an instructional strategy to enhance the reading comprehension skills of fifth-grade remedial readers. Reading Res. Instruction, 31: 41-52.

Even, S., 2008. Moving in (to) imaginary worlds: Drama pedagogy for Foreign language teaching and learning. Die Unterrichtspraxis Teach. Ger., 41: 161-170.

Golinkoff, R.M., K. Hirsh-Pasek and D.C. Singer, 2006. Why Play=Learning: A Challenge for Parents and Educators. In: Play=Learning: How Play Motivates and Enhances Children's Cognitive and Social Emotional Growth, Singer, D.G., R.M. Golinkoffand and K. Hirsh-Pasek (Eds.). Oxford University Press, Oxford, UK., ISBN-13:978--0-19-530438-1, pp: 3-12.

Keehn, S., J. Harmon and A. Shoho, 2008. A study of readers theater in eighth grade: Issues of fluency, comprehension and vocabulary. Reading Writing Q., 24: 335-362.

Lee, B.K., E.A. Patall, S.W. Cawthon and R.R. Steingut, 2015. The effect of drama-based pedagogy on preK-16 outcomes: A meta-analysis of research from 1985 to 2012 . Rev. Educ. Res., 85: 3-49.
Nordin, N.A., N.M. Sharif, N.S. Fong, W.F.A.W. Mansor and M.H. Zakaria, 2012. Fulfilling the tasks of reading, writing, speaking and listening through drama workshop. Procedia Soc. Behav. Sci., 66: 196-202.

Richards, J.C. and T.S. Rodgers, 2001. Approaches and Methods in Language Teaching. 2nd Edn., Cambridge University Press, Cambridge, ISBN: 9780521008433, Pages: 270.

Robinson, S.K. and L. Aronica, 2015. Creative Schools: The Grassroots Revolution That's Transforming Education. Penguin Publishing Group, New York, USA., ISBN:9780698142848, Pages: 320.

Rothwell, J., 2011. Bodies and language: Process drama and intercultural language learning in a beginner language classroom. Res. Drama Educ. J. Appl. Theatre Perform., 16: 575-594.

Straksiene, G., 2015. Explication of activities in the textbooks on developing primary school age childrens communicative competence. Pedagogy., 119: 82-96.

Yates, S.M., 2007. Teachers perceptions of their professional learning activities. Intl. Educ. J., 8: 213-221.

Zigler, E.F. and S.J. Bishop-Josef, 2006. The Cognitive Child Versus the Whole Child: Lessons from 40 Years of Head Start. In: Play=Learning: How Play Motivates and Enhances Children's Cognitive and Social-Emotional Growth, Singer, D.G., R.M. Golinkoff and K. Hirsh-Pasek (Eds.). Oxford University Press, Oxford, UK., ISBN-13:978-0-19-530438-1, pp: 15-35. 